RESEARCH ARTICLE

\title{
Establishment of apple as an appealing cash crop in Sri Lanka: need, challenges, and opportunities
}

W.M.D.A. Wijesundara, N.D.U.S. Nakandala, W.W.M.U.K. Wijesundara, P.W.I. Navanjana, L.T. Ranaweera, H.S.M. Jayarathne, P.G.R.G. Rathanayake, C.K. Weebadde, W.A.R.T. Wickkramaarachchi and S.D.S.S. Sooriyapathirana*

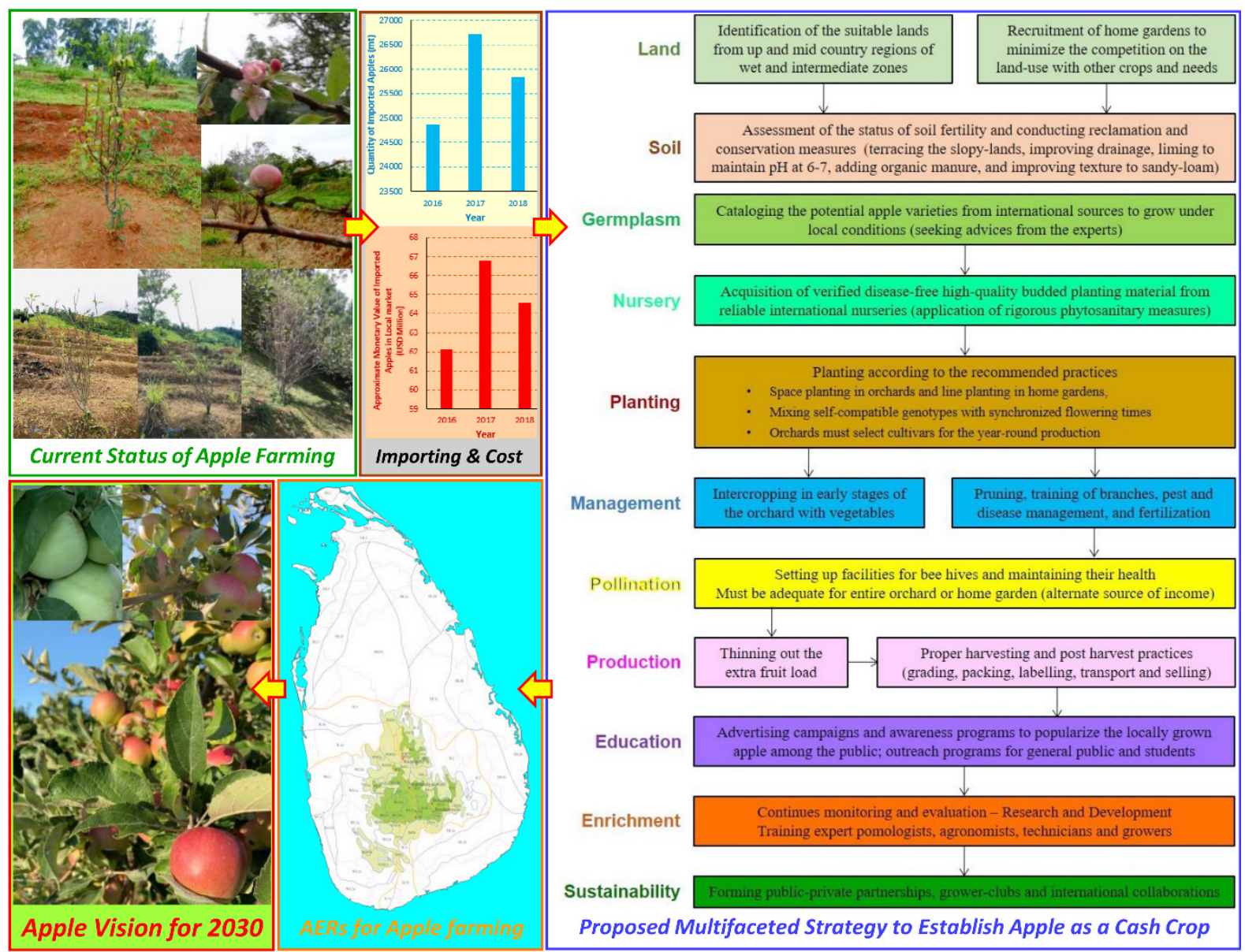

\section{Highlights}

- Sri Lanka imports approximately 25,000 mt of apples annually, which costs on average USD 32.25 million.

- Scattered low productive apple trees are grown in the upcountry wet zone of Sri Lanka.

- S-allele analysis showed that these apple trees possess incompatible SI genotypes for successful pollination.

- The agroecological regions WU1, WU2a, WU2b and WU3 of the up and mid countries of wet and intermediate zones contain the suitable climatic conditions to grow apple. 
RESEARCH ARTICLE

\title{
Establishment of apple as an appealing cash crop in Sri Lanka: need, challenges, and opportunities
}

\author{
W.M.D.A. Wijesundara ${ }^{1}$, N.D.U.S. Nakandala ${ }^{1}$, W.W.M.U.K. Wijesundara ${ }^{1}$, P.W.I. Navanjana ${ }^{1}$, L.T. Ranaweera ${ }^{1}$, \\ H.S.M. Jayarathne ${ }^{1}$, P.G.R.G. Rathanayake' ${ }^{1}$, C.K. Weebadde ${ }^{2}$, W.A.R.T. Wickkramaarachchi ${ }^{3}$, S.D.S.S. Soori- \\ yapathirana ${ }^{1, *}$
}

${ }^{1}$ Department of Molecular Biology and Biotechnology, Faculty of Science, University of Peradeniya, 20400, Peradeniya, Sri Lanka.

${ }^{2}$ Department of Plant, Soil and Microbial Sciences, College of Agriculture and Natural Resources, Michigan State University, East Lansing, Michigan, USA.

${ }^{3}$ National Plant Quarantine Service, Department of Agriculture, Canada Friendship Road, Katunayake, Sri Lanka.

Received: 18/12/2019; Accepted: 25/10/2020

\begin{abstract}
The demand for apple is higher than other fruits in Sri Lanka, and the total of the requirement is achieved through imports causing a massive economic expenditure. A few lowperforming apple trees can be seen in local upcountry regions. However, the feasibility of growing apple in Sri Lanka has not received any attention. The present study was conducted to (1) to assess the quantity imported and the costs associated with importing to Sri Lanka using the statistics available in the National Plant Quarantine Service (NPQS), and (2) observe currently growing apple trees to identify the status of production and their S-allele genotypes to understand whether pollination is likely among the trees. It was further examined the climatic conditions of agro-ecological regions in Sri Lanka to identify suitable areas for apple growing. Nearly 25,000 metric tons of apples are annually imported to Sri Lanka costing USD 32.2 million, a burden to the economy. The apple trees cultivated in Sri Lanka perform well below the standards, and the application of the standard agronomic practices is seldom noticed. We found through PCR and restriction digestion that the trees do not have self-compatible genotypes for pollination. However, the observed apple trees undergo flowering and fruiting at the substandard level implying that local apple production is possible. Apple trees can be grown anywhere in the tropics; however, the best quality apples can be achieved only under the conditions available in up and mid countries of wet and intermediate zones especially in agroecological regions WU1, WU2a, WU2b and WU3. In world-wide information sources, many apple cultivars such as Anna, Dorsett-Golden, and Wambugu are listed for tropical environments. As James Taylor started tea plantations in 1867 , on which Sri Lanka became the world leader in tea production, a dedicated scientific effort must be made to establish an apple industry in Sri Lanka.
\end{abstract}

Keywords: Apple consumption; Apple import; Apple production in Sri Lanka; Farming apples; Growing apples in tropics.

\section{INTRODUCTION}

Apple (Malus $\times$ domestica Bork.) is one of the most important fruit species in the world. Originated within a wide range of Eurasia with the contribution of many progenitor species, apple is currently a global fruit crop with broad geographical adaptability (Cornille et al., 2012; Juniper et al., 1996). Although apple growth and orchards are geographically restricted, apple consumption is almost even everywhere in the world (Agriorbit, 2018). Apple is the third-largest producing fruit crop in the world (World Fruit Map, 2018) and well-established apple industry is functional in many countries. The major producers are China, USA, Poland, Italy and France (US Apple Association, 2019). Apples are eaten fresh (i.e., fruits of table apple cultivars), and, an indispensable ingredient in many desserts such as apple-pie, applecake and diverse beverages like apple juice and cidor (Rupasinghe et al., 2008; van der Sluis et al., 2002).

Sri Lanka is a tropical island with tropical wetevergreen forests, dry deciduous forests, arid regions, and subtropical/montane mountainous regions (Department of Meteorology of Sri Lanka, 2018). The ecological diversity is significant in the country, and the total area of 65,610 $\mathrm{km}^{2}$ has been divided into agro-ecological regions (AER) based on the soil type, land use, vegetation, rainfall and temperature (i.e. elevation) (Department of Agriculture of Sri Lanka, 2003). Currently, the total human population of the country is about 22 million. The Sri Lankans desire to consume apple is phenomenal (Perera and Madhujith, 2012) although the country is blessed with many tropical fruit species. The apples are being sold year-round in every corner of the country. The demand for the apple in Sri Lanka is fully accomplished through imports (Weerahewa et al., 2013). There is no doubt that the importation of apple is causing a severe negative consequence to the country's economy, even though it contributes to increase the social welfare. Sri Lanka as a developing country, 
which looks for all possible avenues to develop the economy, the alternatives to reduce the apple importation is essential to be considered in detail. The demand for apple cannot be replaced with other tropical fruit species in the local market. The demand for apple is colossal that it is not dispensable in Sri Lanka. However, the foreign exchange expenditure caused by the apple-imports on the Sri Lankan economy has not been extensively examined. The National Plant Quarantine Service (NPQS) of the Department of Agriculture, Sri Lanka regulates the importation of any plant material including fruits, nuts, and seeds to the country. Therefore, NPQS has the data for all the imports of any plant material, including apples. We examined these data to understand the amount of "dollar" reserves spent on the apple imports to decide its severity on the country's economy.

Thus, the agricultural scientists are facing a daunting challenge of finding ways to produce apple locally to ease the burden at least partially on the national economy. Given the extreme diversity of AERs in the country and the tremendous variation of global apple germplasm (Troggio et al., 2012), it must be possible to grow apple in Sri Lanka. The country has huge success stories of getting exotic crop species introduced and becoming a world leader in the production quantities with the highest quality. The best examples are tea, rubber, and coffee. Even, relatively new crops like strawberries and many exotic ornamental plants have been successfully introduced and established as remarkably profitable cash crops in Sri Lanka. Although it looks promising and feasible, minimal attention has been given to grow and study the possibility of farming apple in Sri Lanka. The thin silver lining in the cloud is that the small-scale scattered apple-growing fields, and the solitary apple trees can be seen in the upcountry region of Sri Lanka proving that apple can be locally grown. The produce of the locally grown apple trees is hardly reaching the market. The local apple growers speak in the desperation that their apple trees are not producing profitable yield to reach the market. The growers need help from the scientists and legislators to move forward for growing productive apple trees.

When introducing new crop species to a country, it must be conducted scientifically with utmost care. Currently, people grow apple seedlings in Sri Lanka and expect attractive yields. It is a globally proven fact that budded apple trees (high performing apple scions on strong and robust apple or related rootstocks) are needed for profitable fruit production (Jensen et al., 2010; Fallahi et al., 2002). Apple maintains strict self-incompatibility (SI) system (Matsumoto \& Kitahara, 2000; Sakurai et al., 2000). The pollens of the same genotype cannot fertilize the ovules thus careful mixing of different SI genotypes with synchronized flowering times are needed (Kron et al., 2001; Koutinas et al., 2010). All the required agronomic practices for the apple cultivars are readily available in the global knowledge domain (Nesme et al., 2006; Botton et al., 2009; Bertolino et al., 2015). The missing piece of the puzzle is the rigorous implementation of this knowledge to grow apple in Sri Lanka successfully.
In the limelight of growing apple as a cash crop in Sri Lanka, the present study was conducted with three objectives, i.e., the import-related NPQS statistics of apple to Sri Lanka were examined to dissect the exact nature of the economic expenditure, a set of currently growing apple trees were observed to identify the issues pertaining to abysmal productivity, and tested to identify the S-allele genotypes to understand whether successful pollination is possible among the trees. The climatic conditions of AER in Sri Lanka were examined to showcase what kind of apple germplasm should be used to start the commercial programs, and a strategic plan is introduced to direct the establishment of apple as an appealing cash crop in Sri Lanka.

\section{MATERIALS AND METHODS}

\section{Data collection on apple imports}

The fruit importers in Sri Lanka must apply for a permit from NPQS to get the clearance for importing fruits owing to their phytosanitary issues. In the permit application, the importers must specify the quantity, source country, and all the other relevant details. Then NPQS issues the permit and grants permission for the transaction. When the consignment has reached the port, the containers are first stored in the cold room facility, and the NPQS conducts a thorough examination according to the standard procedure to decide the safety for releasing. The NPQS records the imported quantities and details in comparison to what was being requested in the permit. In the present study, the fruit import data collected by NPQS in 2016, 2017, and JanAug of 2018 were examined. The monthly quantities of imports and source countries were reviewed for the apple in comparison to the other fruit types (species) imported to Sri Lanka.

\section{Observation of currently grown apple trees in Sri Lanka and sample collection}

Four apple-growing sites in Sri Lanka were selected (Figure 1) and the tree growth status, health, flowering, fruiting, and other site-related factors were observed. Fifteen healthy trees from an orchard based on the availability and the quality of the trees were selected. The tender leaves were collected to polypropylene bags, transported to the laboratory, and stored at $-80^{\circ} \mathrm{C}$.

\section{DNA extraction, PCR, and restriction digestion}

We used a modified CTAB (hexadecyltrimethylammonium bromide) DNA extraction method as explained in Porebski et al. (1997) to obtain genomic DNA, of which the quality was assessed using 1\% agarose gel electrophoresis, and stored them at $-20{ }^{\circ} \mathrm{C}$. The PCR amplification of different S-RNase alleles was performed in a thermal cycler (TP600: Takara, Otsu Shiga, Japan) using 22 primer pairs using two different PCR programs (Program A and Program B) with specific modifications for optimum amplification [Program A: The initial denaturation was set to $2 \mathrm{~min}$ at 94 ${ }^{\circ} \mathrm{C}$, followed by 35 cycles of $94^{\circ} \mathrm{C}$ for $40 \mathrm{~s}, 58^{\circ} \mathrm{C}$ for $1 \mathrm{~min}$, $72{ }^{\circ} \mathrm{C}$ for $2 \mathrm{~min}$ and finally $72^{\circ} \mathrm{C}$ for $5 \mathrm{~min}$ (Larsen et al., 2016). Program B: The initial denaturation was performed 


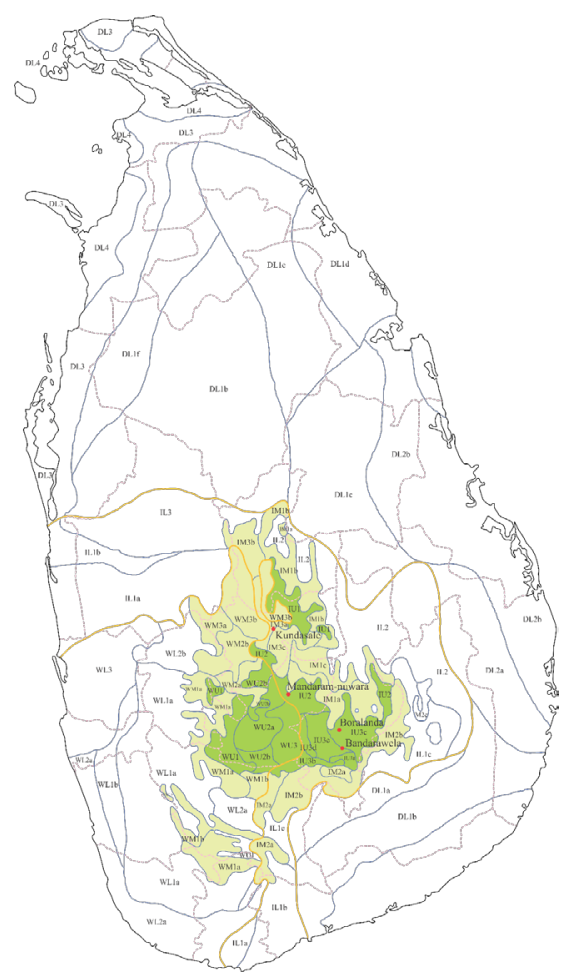

Figure 1: Sampling locations and agro-ecological regions (AER) identified for growing apple in Sri Lanka. Bright green AER represent the best regions and light yellowish green areas indicate the other potential regions to grow apple. The map was drawn based on the information provided in Department of Agriculture, Sri Lanka (2003). Agro ecological regions of Sri Lanka.

Available from: https:/www.doa.gov.lk/images/weather_climate/Krushi_parisarika.jpg

Table 1: Primers for $S$ alleles and their success in PCR amplification

\begin{tabular}{|c|c|c|c|}
\hline $\mathrm{S}$ allele/s & Marker & $\begin{array}{l}\text { Success } \\
\text { of PCR }\end{array}$ & Reference \\
\hline $\begin{array}{l}\text { S1, S2, S4, S6, S7, S9, S11, S20, S21, S23, S24, S26, } \\
\text { S28, S31, S33, S34, S36, S40 }\end{array}$ & $A S P F 3-\mathrm{F}, E I I W P N-\mathrm{R}$ & $\sqrt{ }$ & Larsen et al., (2016) \\
\hline S3, S5, S10, S39, S47 & $A S P F 3-\mathrm{F}, S 3 / S 5 / S 10-\mathrm{R}$ & $\sqrt{ }$ & \\
\hline $\mathrm{S}_{9}$ & FTC154, FTC155 & $\sqrt{ }$ & Broothaerts, (2003) \\
\hline S16 & $A S P F 3-\mathrm{F}, S 16-\mathrm{R}$ & $x$ & \\
\hline S25 & $A S P F 3-\mathrm{F}, S 25-\mathrm{R}$ & $x$ & \\
\hline S8 & $S 8-\mathrm{F}, S 8-\mathrm{R}$ & $x$ & \\
\hline $\mathrm{S}_{1}$ & FTC168, FTC169 & $x$ & \\
\hline $\mathrm{S}_{2}$ & $O W B 122, O W B 123$ & $x$ & \\
\hline $\mathrm{S}_{3}$ & FTC177, FTC226 & $x$ & \\
\hline $\mathrm{S}_{4}$ & FTC5, OWB249 & $x$ & \\
\hline $\mathrm{S}_{5}$ & FTC10, FTC11 & $x$ & \\
\hline$S_{6 b}$ & FTC141, FTC142 & $x$ & \\
\hline $\mathrm{S}_{7}$ & FTC143, FTC144 & $x$ & \\
\hline $\mathrm{S}_{10}$ & FTC12, FTC228 & $x$ & \\
\hline "S $\mathrm{S}_{10 \mathrm{~b}} "\left(\mathrm{~S}_{23}\right)$ & FTC222, FTC224 & $x$ & \\
\hline $\mathrm{S}_{20}$ & FTC141, FTC142 & $x$ & \\
\hline $\mathrm{S}_{24}$ & FTC231, FTC232 & $x$ & \\
\hline $\mathrm{S}_{26}$ & FTC14, FTC9 & $x$ & \\
\hline $\mathrm{S}_{27 \mathrm{a}}\left(\mathrm{S}_{16}\right)$ & FTC5, OWB249 & $x$ & \\
\hline $\mathrm{S}_{27 \mathrm{~b}}$ & FTC5, OWB249 & $x$ & \\
\hline $\mathrm{S}_{28}\left(\mathrm{~S}_{19}\right)$ & FTC229, FTC230 & $x$ & \\
\hline $\mathrm{S}_{14 / 17 / 21} \mathrm{~b}$ & FTC141, FTC142 & $\times$ & \\
\hline
\end{tabular}


at $94{ }^{\circ} \mathrm{C}$ for $5 \mathrm{~min}$, followed by 35 cycles of $94^{\circ} \mathrm{C}$ for $30 \mathrm{~s}$, $55^{\circ} \mathrm{C}$ for $1 \mathrm{~min}, 72^{\circ} \mathrm{C}$ for $2 \mathrm{~min}$ and finally $72^{\circ} \mathrm{C}$ for $5 \mathrm{~min}$ (Broothaerts, 2003)]. The details of primer pairs and their success of amplification are given in Table 1. Each reaction was performed in $30 \mu \mathrm{l}$ reaction mixture containing $2 \times$ Go Taq Green Master Mix $(15 \mu \mathrm{l}), 10 \mu \mathrm{M}$ forward and reverse primers $(1 \mu \mathrm{l}$ each) and $10 \mu \mathrm{M}$ spermidine $(7 \mu \mathrm{l})$.

The PCR products were purified using the Promega DNA purification kit (Promega Corporation, Madison, Wisconsin, USA). The restriction digestion was carried out for the purified DNA with the enzymes RsaI and TaqaI
(Larsen et al., 2016) in $10 \mu \mathrm{l}$ reaction mixture consisting of $1 \mu \mathrm{l}$ of $10 \times \mathrm{CutSmart} \AA$ buffer, $0.5 \mu \mathrm{l}$ of restriction enzyme, $7 \mu \mathrm{l}$ of purified DNA and $1.5 \mu \mathrm{l}$ sterile distilled water. The reaction mixtures were kept at $37^{\circ} \mathrm{C}$ and $65^{\circ} \mathrm{C}$ for $15 \mathrm{~min}$ to complete the digestion. The digested and undigested PCR products were subjected to $2 \%$ agarose gel electrophoresis along with a DNA ladder to size-determine the digested products. The S-alleles genotypes were deduced from the banding patterns on the agarose gels according to the information given in Larsen et al., (2016) and Broothaerts, (2003) (Table 1).

Table 2: The annual import of fruits to Sri Lanka.

\begin{tabular}{lccc}
\hline \multirow{2}{*}{ Imported Fruits } & \multicolumn{3}{c}{ Quantity (metric tons) } \\
\cline { 2 - 4 } & $\mathbf{2 0 1 6}$ & $\mathbf{2 0 1 7}$ & $\mathbf{2 0 1 8}$ (Jan - Aug) \\
\hline Apples & 24861 & 26722 & 17227 \\
\hline Grapes & 6159 & 7269 & 4831 \\
\hline Mandarine & 10340 & 8196 & 7280 \\
\hline Oranges & 8203 & 8959 & 5205 \\
\hline Pomegranate & 2642 & 2147 & 1179 \\
\hline Pears & 380 & 329 & 238 \\
\hline $\begin{array}{l}\text { Other (Kiwi fruit, Nectarine, Grape fruit, } \\
\text { Plums, Strawberry [Frozen], and Cherry) }\end{array}$ & 194 & 157 & 60 \\
\hline Total Quantity & $\mathbf{5 2 7 7 9}$ & $\mathbf{5 3 7 7 9}$ & $\mathbf{3 6 0 2 0}$ \\
\hline
\end{tabular}

A

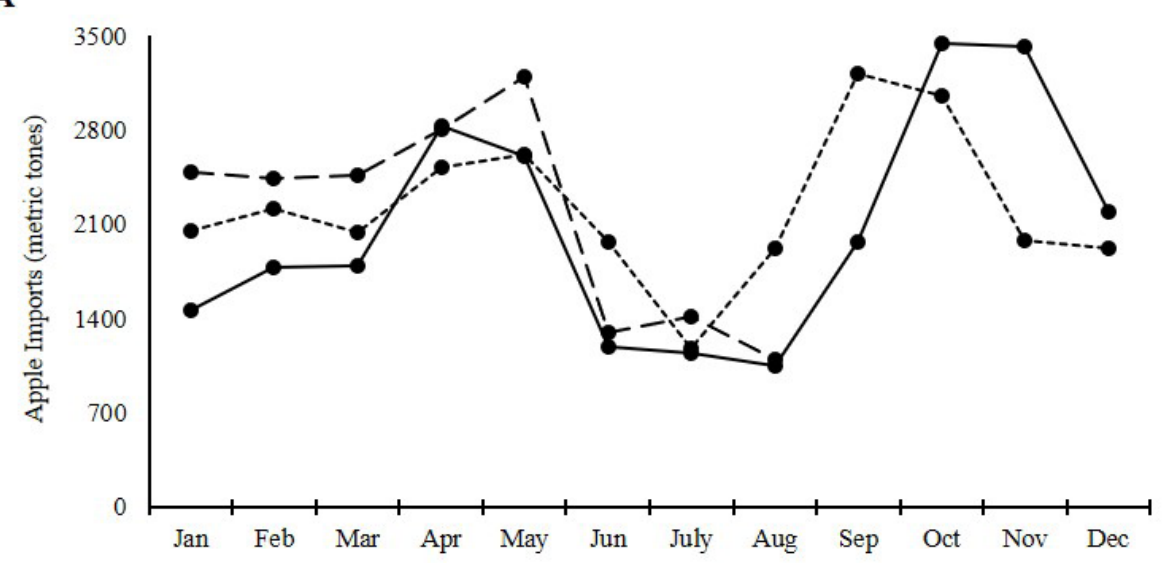

B

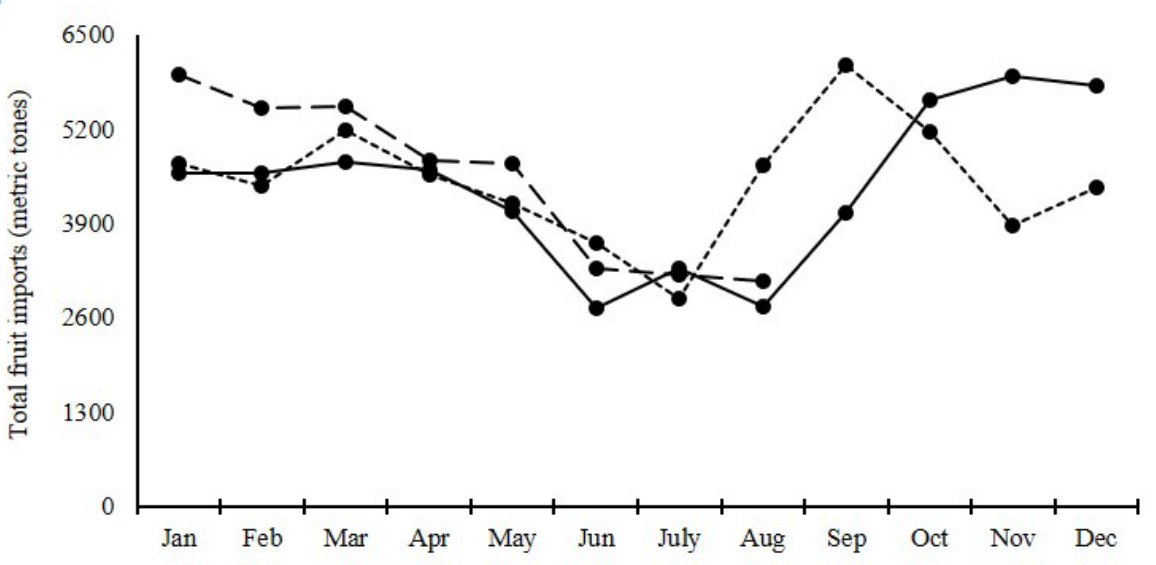

Figure 2: The quantitative variation of the fruit importations to Sri Lanka. A: Apple imports; B: Total imports. Solid line: 2016; Small dashed line: 2017; Large dashed line: 2018. For 2018, the data are only available till August. 


\section{Identification of the potential AER for growing apple in Sri Lanka}

The mean rainfall, temperature, and elevation of the AERs of Sri Lanka were examined using the published records. The conditions were compared with other apple-growing regions in the world where winter is not prevailing in any part of the year. Further, the potential apple varieties were chosen based on the published lists of cultivars for tropical regions to initiate the apple cultivations in the identified AERs of Sri Lanka.

\section{RESULTS AND DISCUSSION}

\section{Economic expenditure of importing apple}

\section{Annual and monthly variation of apple imports}

According to the statistics available for 2016, 2017 and 2018 (January-August), annually Sri Lanka imports 50,000-55,000 mt of fruits (estimated amount for 2018 was $54,030 \mathrm{mt}$ ). A similar trend could be seen for apples, and the annual amount of importing is in the range of 24,000$27,000 \mathrm{mt}$ (estimated amount for 2018 was $25,841 \mathrm{mt}$ )

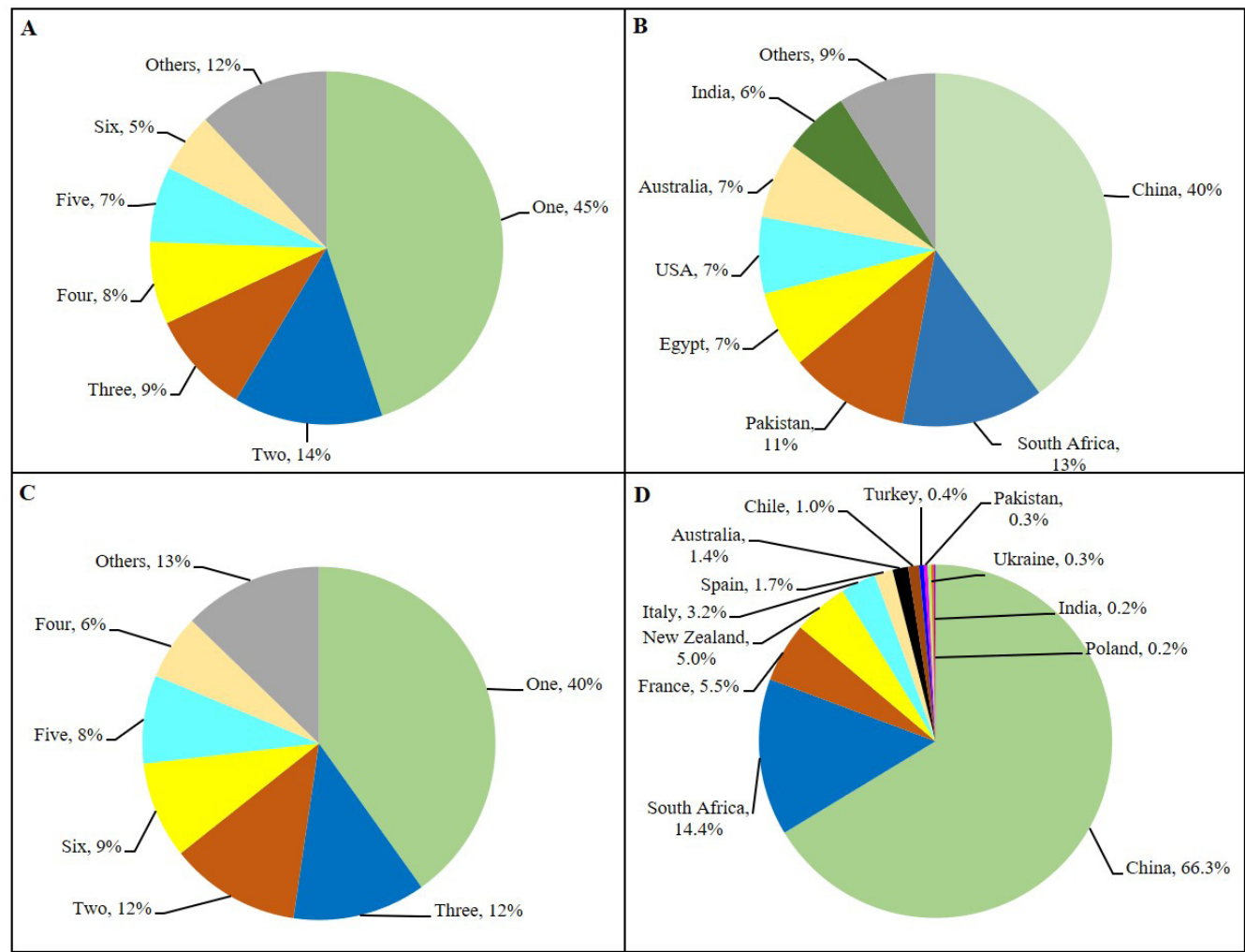

Figure 3: Important statistics regarding the fruit importations to Sri Lanka (2016-2018). A: The proportions of the fruits imported by the companies/people (one-six represents the company/person IDs) [six companies mainly run the importations; B: The source countries and the proportions - fruit imports; C: The proportions of the apple imported by the companies/people (one-six represents the company/person IDs comparable with Graph A); D: The source countries and the proportions - apple imports.

Table 3: The quantities of apples requested to be imported in comparison to the other fruit types in 2017 and the actual quantities imported

\begin{tabular}{lccc}
\hline Type of fruit/s & $\begin{array}{c}\text { Quantity of fresh fruits } \\
\text { (mt) indicated on the } \\
\text { import permits issued }\end{array}$ & $\begin{array}{c}\text { Quantity of actual } \\
\text { imports of fresh } \\
\text { fruits (mt) }\end{array}$ & $\begin{array}{c}\text { Actual quantity (\%) of fruits } \\
\text { imported in comparison to how } \\
\text { much requested on the permits } \\
\text { issued }\end{array}$ \\
\hline Apple & 360,107 & 26,722 & 7.42 \\
Orange & 254,733 & 8,959 & 3.52 \\
Mandarin & 227,148 & 8,196 & 3.61 \\
Grapes & 255,604 & 7,269 & 2.84 \\
Pomegranate & 137,187 & 2,147 & 1.56 \\
Pears & 90,175 & 329 & 0.36 \\
Other (Nectarine, Peaches, Kiwi, Plums, & 119,139 & 157 & 0.13 \\
Grapefruit, Cherry, Berry etc.) & & & $\mathbf{3 . 7 2}$ \\
\hline Total & $\mathbf{1 , 4 4 4 , 0 9 3}$ & $\mathbf{5 3 , 7 7 9}$ & \\
\hline
\end{tabular}


(Table 2). The apple imports to Sri Lanka is $47 \%-50 \%$ out of the total fruits imported in weight basis (Table 3).

The monthly variation of the fruit imports to Sri Lanka is shown in Figure 2. The peak imports of fruits including apples, coincide with the festive seasons of Sri Lanka (Figures 2A and 2B). During the Sinhala and Tamil newyear season in April and Vesak festival in May, the apple imports are higher. However, during the Christmas season (December), which is the winter for many apple producing countries, apple imports are less, however, it is evident that Sri Lankan apple importers get their apple stocks in late fall (October-November) and keep stored for the Christmas season, which has the highest demand for fruits (Figure 2). This was evident by contribution of apple imports (nearly $50 \%$ of the total fruit imports) to the country (Table 3 ). It is interesting to note that both apple and total fruit imports display the lowest figures from June-August. This pattern must be due to the peak production season of local fruits such as mango, wood apple, rambutan, and many others. During this time, the market is dominated by local fruits, however, nearly 1200-1400 mt of apples and 2900-3800 mt of exotic fruits are still demanded by the customers.

\section{Importers and source countries}

The importation of fruits to Sri Lanka is mainly carried out by six companies/people. Out of them, one company imports $45 \%$ of the total fruits (Figure 3A). Mainly fruits are imported from seven countries and $40 \%$ is imported from China (Figure 3B). Like the total fruit imports, apple imports are also mainly run by the same six companies. Company 'one' imports $40 \%$ dominating the market (Figure 3C). Apple is imported from 13 countries, however, $66.3 \%$ is coming from China (Figure 3D).

\section{Estimated cost for importing apple}

On average, 25,808 $\mathrm{mt}$ of apples are annually imported to Sri Lanka. The prices at which Sri Lankan importers purchase apples from the source-countries are not available for analysis. However, based on the market prices of apples, the approximate cost of annual apple imports could be estimated. The average retail prices of the apples in supermarkets and street-vendors are LKR 450,000 and LKR 425,000 per mt, respectively from 2016-2018. If we assume, $50 \%$ each of the imported apple stocks are being sold in the supermarkets and the street-vendors, the mean retail price of the apples is LKR 437,500 per mt. Even if ratios of the apple market shared between the supermarkets and the street-vendors are not 1:1, the two retail price values could be assumed a mean retail price as LKR 437,500 per $\mathrm{mt}$. The total retail value of the imported apples is thus estimated to be LKR 11,291,000,000 (eleven billion two hundred and ninety-one), which is calculated by multiplying the quantity with the mean retail value per mt. With the current exchange rate, this value is approximately USD 64.5 million. If $50 \%$ of this figure is deducted for shipping, taxes, labor, transport, damages/losses, miscellaneous factors, and profit, USD 32.25 million is annually required to import apples to Sri Lanka (Table 4). This estimated figure is approximately equal to the total export value of nutmeg and mace in 2016 (Economic and Social Statistics of Sri Lanka, 2018). It is clear that importing apples to Sri Lanka is a huge burden on the national economy, and it is important to look for the avenues of local production. Although it has not been proven scientifically, the consumers frequently complain about the quality of apples available in the market (Pers. Com). The quality standards required for Table Apples (also for cold storage apples) are clearly listed in Sri Lanka Standards Institute, (2020). However, the presence of partially deteriorated apples in the market would occur due to prolonged and improper storage facilities and many middlemen before reaching the customers (Porat et al., 2018). It has also been reported that imported apples contain noxius plant pathogens (De Silva et al., 2002). Also, it has been stated that these sort pathogens were responsible for the demise of the apple trees existed in hill countries of Sri Lanka (Kelaniyangoda, and Heenkenda, 1993; reviewed in De Silva et al., 2002). If good quality apple can be produced locally, consumer satisfaction can be guaranteed by fast-tracking the distribution process.

\section{Requested and actual quantities of apple imports}

All fruit imports to Sri Lanka is carried out under the import permits issued by NPQS. The import-permits are issued free of charge upon the requests of importers. We assessed whether the importers would bring the entire quantity that they mentioned in the permits. Table 3 shows that although

Table 4: The estimated cost for importing apple to Sri Lanka.

\begin{tabular}{|c|c|c|c|c|c|c|c|}
\hline \multirow{2}{*}{ Year } & \multirow{2}{*}{$\begin{array}{l}\text { Imported } \\
\text { quantity } \\
\quad(\mathrm{mt})\end{array}$} & \multicolumn{3}{|c|}{$\begin{array}{l}\text { Approximate average market } \\
\text { price for consumers }(\mathrm{LKR} / \mathrm{mt})\end{array}$} & \multirow{2}{*}{$\begin{array}{l}\text { Total value } \\
\text { (LKR) } \\
\text { (quantity } \times \\
\text { mean) }\end{array}$} & \multirow{2}{*}{$\begin{array}{c}\text { Total value } \\
\text { (USD) } \\
\text { (1 USD = 175 } \\
\text { LKR) } \\
\text { [Total value } \\
\text { (LKR)/175] }\end{array}$} & \multirow{2}{*}{$\begin{array}{l}50 \% \text { of the } \\
\text { total value (USD) } \\
\text { (approximate } \\
\text { import-cost) }\end{array}$} \\
\hline & & Supermarket & $\begin{array}{c}\text { Street- } \\
\text { vendors }\end{array}$ & Mean & & & \\
\hline 2016 & 24861 & \multirow{5}{*}{450,000} & \multirow{5}{*}{425,000} & \multirow{5}{*}{437,500} & $10,876,687,500$ & $62,152,500$ & $31,076,250$ \\
\hline 2017 & 26722 & & & & $11,690,875,000$ & $66,805,000$ & $33,402,500$ \\
\hline 2018 (estimated) & 25841 & & & & $11,305,437,500$ & $64,602,500$ & $32,301,250$ \\
\hline \multirow[t]{2}{*}{ Mean annual } & 25808 & & & & $11,291,000,000$ & $64,520,000$ & $32,260,000$ \\
\hline & & & & & & $\sim 64.5$ million & $\sim 32.25$ million \\
\hline
\end{tabular}


NPQS has issued import-permits for a massive amount of 1,444,093 $\mathrm{mt}$ in 2017, the import-permit holders (i.e., importers) have only brought $53,779 \mathrm{mt}$ of fruits $(3.72 \%)$ to Sri Lanka in the same year. Further, out of import request of 360,107 $\mathrm{mt}$ of apples made in 2017, only 26,722 $\mathrm{mt}$ (7.42 $\%$ ) have been imported to the country. The extra quantities stated in import permits may enable the importer to adjust the quantities imported according to the market demand, price fluctuations in source countries, and the availability of funds for the investment.

\section{Status of the currently grown apple trees and locations}

We found that the apple trees grown in the studied locations are not subjected to the necessary agronomic practices to grow optimally or produce acceptable yields. Although the trees are old enough to provide the economic yields, they are performing poorly (Figures 4A-H) compared to fruitful trees/branches grown in Michigan, USA (Figures
5A-I). It seems that most of the times, seedlings are grown without using budded or grafted plants. The pruning and training of branches that are mandatory for successful productivity (Ferree, 2019; Jackson, 2003) are not being practiced. Mostly the plants are grown in marginal lands with degraded soils that are prone to frequent soil erosion. Soil conservation and reclamation practices are hardily seen. Since apple trees thrive well in loamy to sandy loam soils with pH 6-7 (Jackson, 2003), soil fertility management is essential. The trees are sparsely grown, not closely spaced and with non-synchronized flowering to occur successful pollination of each other. No attempts have been placed to introduce bees as they are essential pollinating agents (Orcheski \& Brown, 2012). Thus, it is not surprising to see that the trees show poor growth and negligible yields. However, it is important to note that the flowering (Figure 4I), and the fruit set (Figures 4J-L) occur under the climatic conditions of the sites (Figure 1) that we
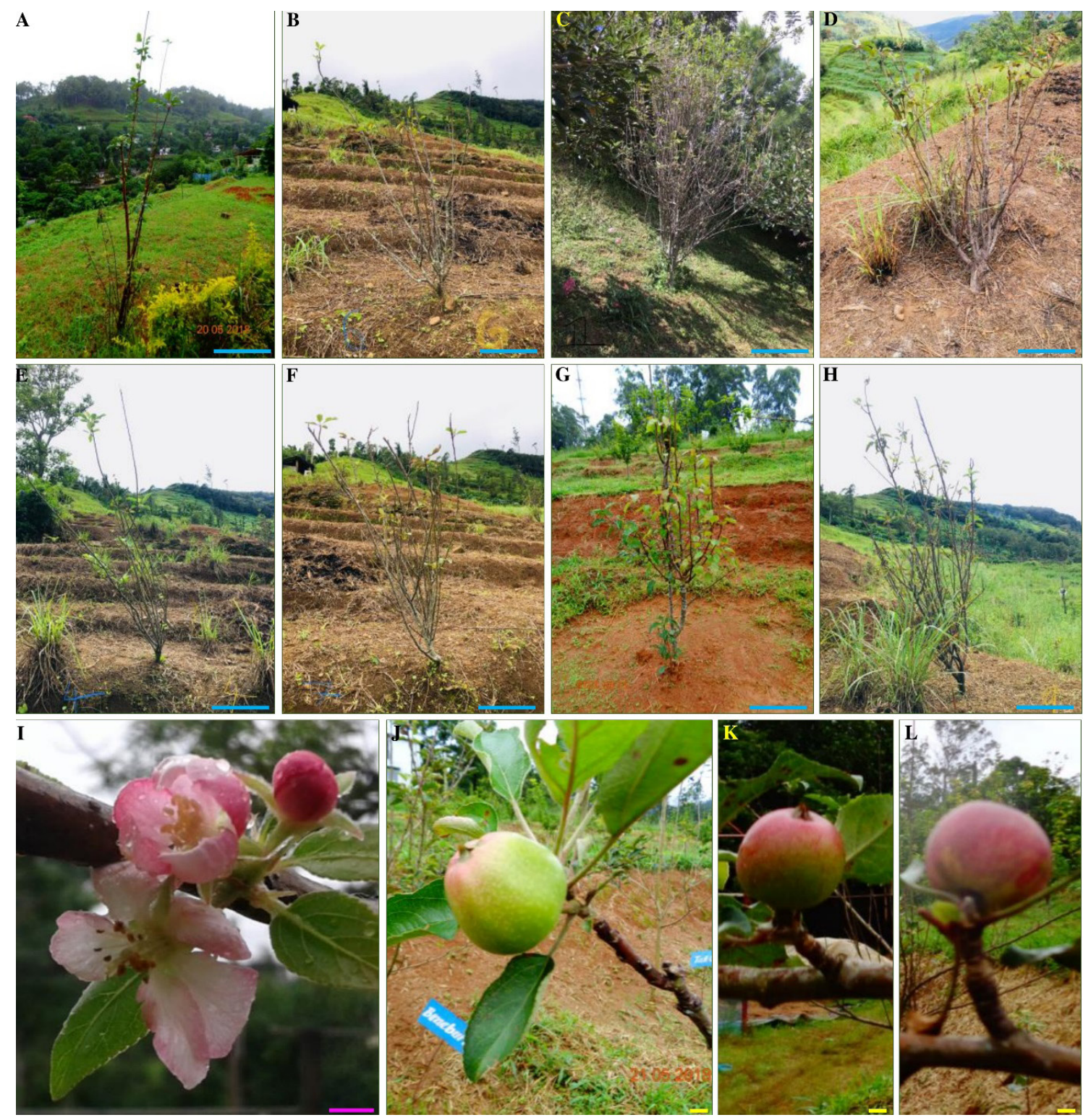

Figure 4: A set of apple trees currently growing in Sri Lanka. A-H: Eight different trees; I: Flower cluster; J: Fruits nearing harvesting stage. The scale bars for trees, flower and fruits represent $40 \mathrm{~cm}$ and $1 \mathrm{~cm}$ respectively. 

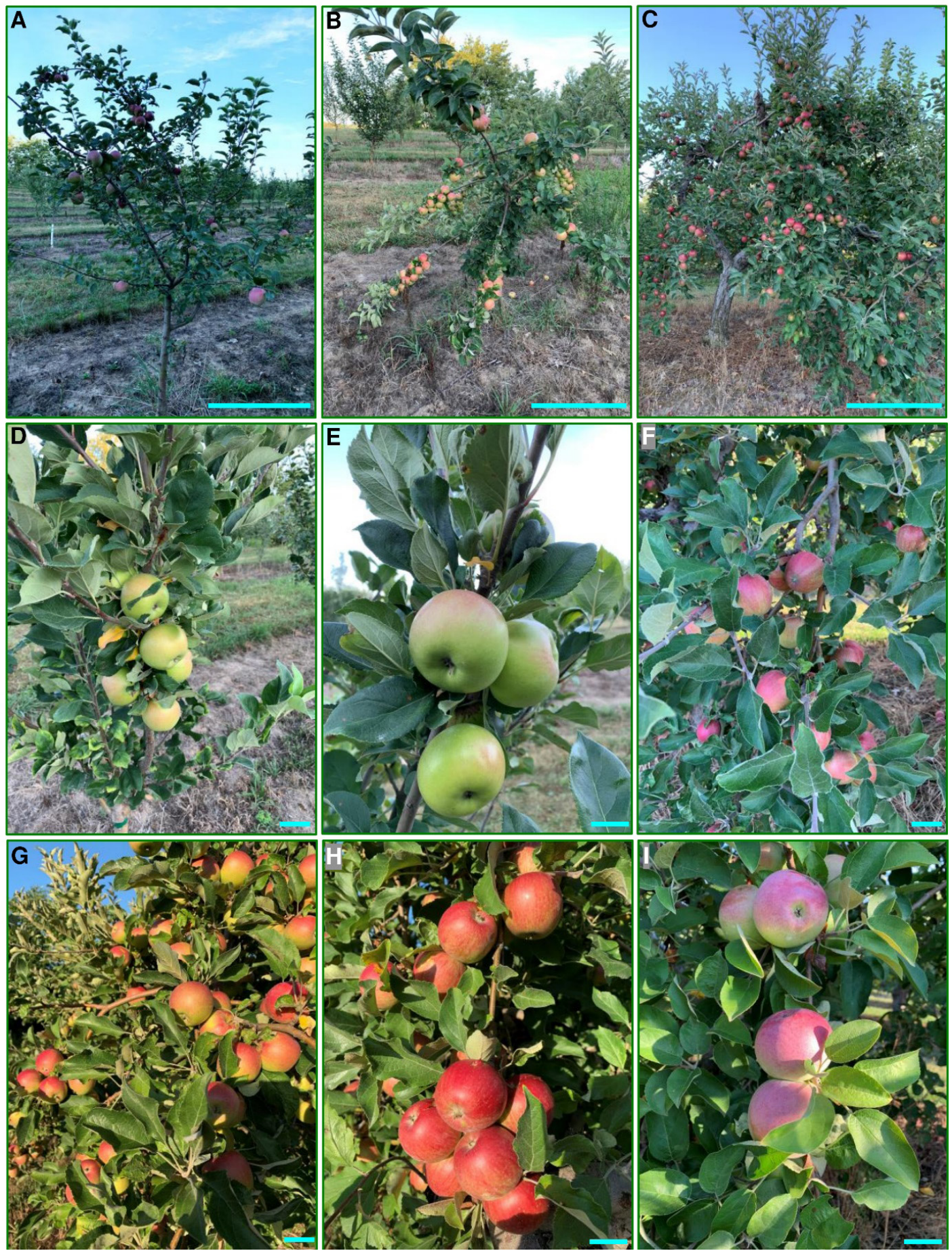

Figure 5: A set of productive apple trees currently growing in Michigan, USA during summertime are shown for comparison purpose. A-C: Three different trees; D-I: Fruit bearing branches. The scale bars for trees and fruit bearing branches represent $1 \mathrm{~m}$ and $1 \mathrm{~cm}$ respectively.

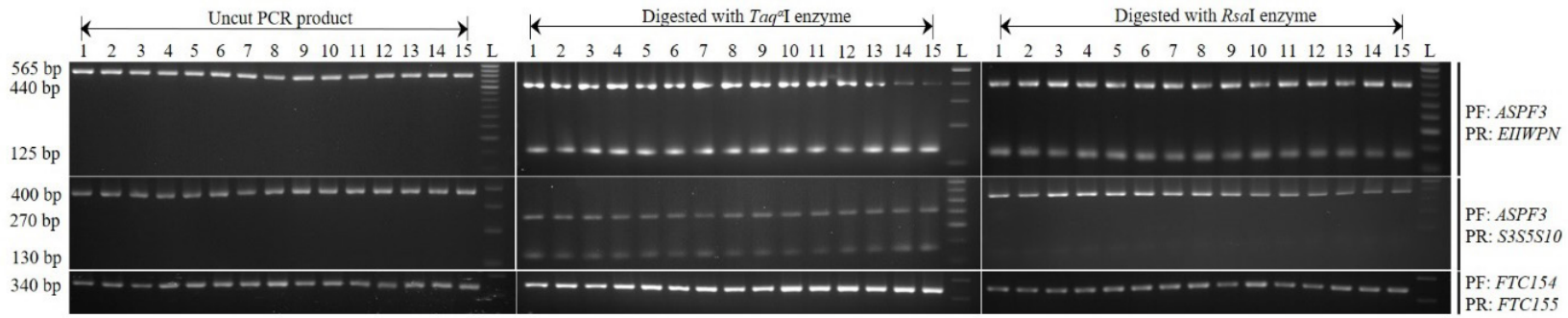

Figure 6: Agarose gel images displaying the PCR products amplified with three markers and the digested PCR products with the restriction enzymes $T a q^{\alpha} \mathrm{I}$ and $R s a I$. 1-15 represent apple trees sampled. 
Table 5: Identification of the conducive AER for growing apples in Sri Lanka.

\begin{tabular}{|c|c|c|c|c|c|c|c|}
\hline \multirow{3}{*}{$\begin{array}{l}\text { Climatic Zone } \\
\text { Wet zone }\end{array}$} & \multirow{2}{*}{\multicolumn{2}{|c|}{ Agro-ecological region (AER) }} & \multirow{3}{*}{$\begin{array}{c}\text { Expected annual rainfall }(\mathrm{mm}) \\
\qquad \text { Min } \\
>3100 \\
\end{array}$} & \multicolumn{2}{|c|}{ Temperature $\left({ }^{\circ} \mathrm{C}\right)$} & \multicolumn{2}{|c|}{ RH (\%) } \\
\hline & & & & \multirow{2}{*}{$\frac{\operatorname{Max}}{2-10^{*}}$} & \multirow{2}{*}{$\frac{\text { Day }}{15-25}$} & \multicolumn{2}{|c|}{ Night } \\
\hline & Up country & WU1 & & & & $35-60$ & $70-80$ \\
\hline & & WU2a & $>2400$ & & & & \\
\hline & & WU2b & $>2200$ & & & & \\
\hline & & WU3 & $>1800$ & & & & \\
\hline & Mid country & WM1a & $>3300$ & $18-22$ & $27-33$ & $55-80$ & $75-85$ \\
\hline & & WM1b & $>2900$ & & & & \\
\hline & & WM2a & $>2200$ & & & & \\
\hline & & WM2b & $>1800$ & & & & \\
\hline & & WM3a & $>1600$ & & & & \\
\hline & & WM3b & $>1400$ & & & & \\
\hline & Low country & WL1a & $>3200$ & $22-24$ & $32-35$ & $60-75$ & 90 \\
\hline & & WL1b & $>2800$ & & & & \\
\hline & & WL2a & $>2400$ & & & & \\
\hline & & WL2b & $>2200$ & & & & \\
\hline & & WL3 & $>1700$ & & & & \\
\hline \multirow{20}{*}{$\begin{array}{l}\text { Intermediate } \\
\text { zone }\end{array}$} & Up country & IU1 & $>2400$ & $13-18$ & $22-29$ & $60-82$ & 90 \\
\hline & & IU2 & $>2100$ & & & & \\
\hline & & IU3a & $>1900$ & & & & \\
\hline & & IU3b & $>1700$ & & & & \\
\hline & & IU3c & $>1600$ & & & & \\
\hline & & IU3d & $>1300$ & & & & \\
\hline & & IU3e & $>1400$ & & & & \\
\hline & Mid country & IM1a & $>2000$ & $18-23$ & $28-33$ & $55-75$ & $75-85$ \\
\hline & & IM1b & $>2000$ & & & & \\
\hline & & IM1c & $>1300$ & & & & \\
\hline & & IM2a & $>1800$ & & & & \\
\hline & & IM2b & $>1600$ & & & & \\
\hline & & IM3a & $>1400$ & & & & \\
\hline & & IM3b & $>1200$ & & & & \\
\hline & & IM3c & $>1100$ & & & & \\
\hline & Low country & IL1a & $>1400$ & $20-26$ & $29-35$ & $55-75$ & 90 \\
\hline & & IL1b & $>1100$ & & & & \\
\hline & & IL1c & $>1300$ & & & & \\
\hline & & IL2 & $>1600$ & & & & \\
\hline & & IL3 & $>1100$ & & & & \\
\hline \multirow[t]{11}{*}{ Dry Zone } & Low country & DL1a & $>1100$ & $20-26$ & $29-38$ & $50-75$ & 90 \\
\hline & & DL1b & $>900$ & & & & \\
\hline & & DL1c & $>900$ & & & & \\
\hline & & DL1d & $>900$ & & & & \\
\hline & & DL1e & $>900$ & & & & \\
\hline & & DL1f & $>800$ & & & & \\
\hline & & DL2a & $>1300$ & & & & \\
\hline & & DL2b & $>1100$ & & & & \\
\hline & & DL3 & $>800$ & & & & \\
\hline & & DL4 & $>750$ & & & & \\
\hline & & DL5 & $>650$ & & & & \\
\hline
\end{tabular}

The dark-grey and light-grey areas can be identified as the AER (Figure 1) with optimum and sub-optimum conditions respectively for apple cultivation. Sources: Punyawardane, (2009); Senanayake et al., (2017); Crop Rec Database, Natural Resources Management Center of DOA, Sri Lanka (2017). 

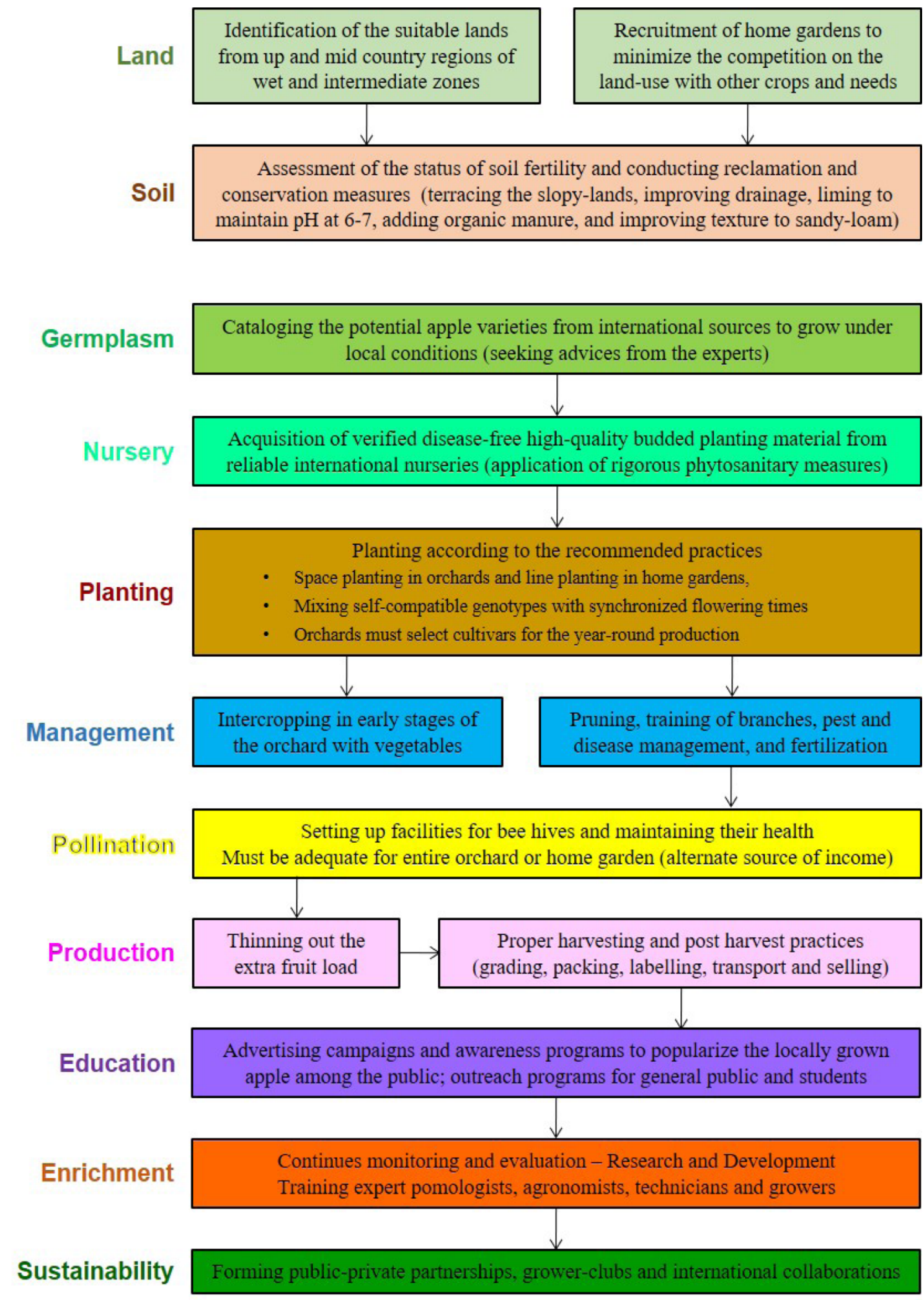

Figure 7: An integrated plan summarizing the steps needed to establish apple as a cash crop.

observed. Hence, under the provision of proper agronomic practices, productive apple trees can be grown under these conditions in Sri Lanka.

\section{S-allele genotypes}

According to the S-allele genotype identification guide of Broothaerts (2003), all the genotyped apple trees must have the allele $\mathrm{S}_{9}$. All trees yielded a band for the primer pair FTC154 and FTC155. The presence of the monomorphic band of 390bp for the primer pair ASF3 and S3S5S10, followed by the digestion with $T_{a q}{ }^{a} I$ and $R s a I$ indicated that the all trees must have the allele $S 5$. The band of $565 \mathrm{bp}$ for ASF3 and EIIWPN, digestion with Taq ${ }^{\alpha} I$ (produced three bands: $440 \mathrm{bp} \mid 125 \mathrm{bp}$ ) and with RsaI (440bp|125bp) 
indicated that the tress must also have the allele $\mathrm{S}_{24}$ (Figure $6)$. For all the other $19 \mathrm{~S}$-allele primer pairs, we did not observe any successful PCR amplification (Table 1). Therefore, the $\mathrm{S}$-allele genotypes of the assessed tress are triploid $\left(\mathrm{S}_{9} \mathrm{~S}_{10} \mathrm{~S}_{24}\right)$ indicating that the successful pollination events must be extremely difficult. The polyploid apple trees produce mostly sterile pollens (Orcheski \& Brown, 2012) and ineffective as pollinizing trees. The polyploid trees need effective pollinizing trees with completely selfcompatible genotypes. For the trees that we assessed, a fully self-compatible pollinizer must be a diploid to produce fertile pollens and devoid of $\mathrm{S}_{9}, \mathrm{~S}_{10}$, or $\mathrm{S}_{24}$. It is apparent that no emphasis has been made to select self-compatible genotypes when planting these trees which is apparent with their low fruit set.

\section{Potential agro-ecological regions (AER) and cultivars for growing apple in Sri Lanka}

Given the wide range of geographical origin of the modernday apple, the crop could be able survive any climatic zone except arid regions. It was believed that apple could not be grown in warm tropical regions because of the requirement of chilling hours for flowering (Legave et al., 2013). However, the low-chill varieties (require less than 200 chilling hours) have been developed, and they can be grown in tropical areas. Apple can be grown in warmer areas with mean temperature of $30{ }^{\circ} \mathrm{C}$ and relative humidity (RH) around 75\% - 90\%. However, the crispiness (crunchiness) of the fruits, which is a mandatory taste-trait in the market, reduces and fruits become mushy in texture. This is not desirable at any level of the fresh apple market. The fruits can also get sunburned, leading to great yield losses and higher RH levels usually cause severe fungal infestations. Therefore, low country wet zone, low country intermediate zone, and the entire dry zone have to be ruled out for apple cultivation in Sri Lanka (Figure 1; Table 5). The best condition for apple trees can be identified in all AERs of the upcountry wet zone (Figure 1). The conditions in these AERs are comparable with the apple-growing regions of Uganda, Nigeria, and Kenya (Ruto, 2018; Kuffel Creek Apple Tree Nursery, 2018; Graduate Farmer, 2016). The AERs of mid-country of the wet zone, and up and mid countries of the intermediate zone should also be considered as their conditions are suboptimal (Figure 1; Table 5) and find fitting varieties should be selected for specific locations. In the present study, we also observed apple trees growing at Kundasale (IU1) of the Kandy district.

In Kenya, an apple-landrace named 'Wambugu' (an apple landrace identified by a farmer Mr. Peter Wambugu) has been grown in Nyeri county with a mean annual rainfall $1004 \mathrm{~mm}$, and mean temperature $17.1^{\circ} \mathrm{C}$ (IAMAT, 2019)]. The Wambugu apple trees are strong, long-living, with no signs of SI, and getting popular throughout Kenya and the rest of Africa (Graduate Farmer, 2016).

\section{Integrated plan for establishing apple as a cash crop in Sri Lanka}

The knowledge of genetics, agronomy, post-harvest technology, and all socioeconomic aspects of apple production are available in the public domain. In the process of introducing and establishing apple cultivation in Sri Lanka, a carefully crafted coordinated action plan must be devised and followed. Figure 7 illustrates such a plan with 11 aspects starting from the selection of lands to the measures needed for sustainability. Once lands or home gardens are selected, based on the action plan illustrated in Figure 7, the grower should device a more detailed implementation plan with the help of experts. The wellestablished and managed apple trees start the production after one to two years and continue to produce economic yields for 100-200 years according to the available reports. The initial establishment would be challenging, which is characteristic to any venture capital business, however, the perennial nature of the crop will provide sustainable dividends for years and to many generations.

\section{CONCLUSION}

Sri Lanka imports approximately $25,000 \mathrm{mt}$ of apples annually, which cost around USD 32.25 million, causing a significant liability to the national economy. There are underperforming apple trees grown in the wet zone of Sri Lanka under sub-optimal conditions. It seems that these apple trees do not have the matching SI genotypes for successful pollination and fertile pollen production. However, the trees flower and set few fruits proving that apple can be grown in Sri Lanka. When compared to the other apple-growing regions of the tropical countries like Nigeria, Uganda, and Kenya, there is a vast potential to grow apple in Sri Lanka selecting suitable locations in up and mid countries of wet and intermediate zones. There are many apple varieties like Anna, Dorsett- Golden, and Wambugu listed suitable for growing under tropical conditions.

\section{ACKNOWLEDGMENTS}

We acknowledge the owners of the apple tree sites for granting the access, provision of information and permission to collect samples and National Plant Quarantine Service, Department of Agriculture, Canada Friendship Road, Katunayake, Sri Lanka.

\section{DECLARATION OF CONFLICT OF INTEREST}

Authors declare no conflict of interest.

\section{REFERENCES}

Agriorbit (2018). Global apple consumption continues to grow. Available from: https://www.agriorbit.com/ global-apple-consumption-continues-to-grow/ August 2020).

Bertolino, S., Asteggiano, L., Saladini, M.A., Giordani, L., Vittone, G. and Alma, A. (2015). Environmental factors and agronomic practices associated with Savi's pine vole abundance in Italian apple orchards. Journal of Pest Science 88(1): 135-142.

Botton, A., Lezzer, P., Dorigoni, A., Ruperti, B. and Ramina, A. (2009). Environmental factors affecting the expression of apple (Malus $\times$ domestica L. Borkh) allergen-encoding genes. The Journal of Horticultural Science and Biotechnology 84(6):182-187. 
Broothaerts, W. (2003). New findings in apple S-genotype analysis resolve previous confusion and request the renumbering of some S-alleles. Theoretical and Applied Genetics 106(4): 703-714.

IAMAT (2019). Kenya: Climate Information by City. International Association for Medical Assistance to Travelers. (IAMAT) Available from: https://www.iamat. org/country/kenya/climate-data (16 August 2020).

Cornille, A., Gladieux, P., Smulders, M.J., Roldan-Ruiz, I., Laurens, F., Le Cam, B., Nersesyan, A., Clavel, J., Olonova, M., Feugey, L. and Gabrielyan, I. (2012). New insight into the history of domesticated apple: secondary contribution of the European wild apple to the genome of cultivated varieties. PLoS Genetics 8(5): p.e1002703.

Department of Agriculture, Sri Lanka (2003). Agro ecological regions of Sri Lanka. Available from: https:// www.doa.gov.1k/images/weather_climate/Krushi_ parisarika.jpg (16 August 2020).

Department of Meteorology, Sri Lanka (2018). Available from: http://www.meteo.gov.lk/index.php?lang=en (16 August 2020).

De Silva, R.S.Y., Amarakoon, A.R.W.M.M.U.M. and Nilangika, P.H. (2002). Plant pathogens in fruits imported into Sri Lanka. Annals of the Sri Lanka Department of Agriculture 4: 419-423.

Economic and Social Statistics of Sri Lanka (2009). Centra Bank of Sri Lanka. Available from: https://www.cbsl. gov.lk/en/publications/other-publications/statistical publications/ economic -and-social-statistics-of-srilanka (16 August 2020).

Fallahi, E., Colt, W.M., Fallahi, B. and Chun, I.J. (2002). The importance of apple rootstocks on tree growth, yield, fruit quality, leaf nutrition, and photosynthesis with an emphasis on 'Fuji'. HortTechnology 12(1): 3844.

Ferree, M.E. (2019). Home garden apples. Available from: https://secure.caes.uga.edu/extension/publications/ files/pdf/C\%20740_6.PDF (16 August 2020).

Graduate Farmer (2016). Graduate Farmer: Agribusiness made possible. Available from: https:/graduatefarmer. co.ke/2016/11/24/smallholder-farmers-guide-to-dairyfarming-as-a-business-part-1/farm-plan/ (16 August 2020).

Jackson, J.E. (2003). Biology of apples and pears. Cambridge University Press Pp. 415-442.

Jensen, P.J., Makalowska, I., Altman, N., Fazio, G., Praul, C., Maximova, S.N., Crassweller, R.M., Travis, J.W. and McNellis, T.W. (2010). Rootstock-regulated gene expression patterns in apple tree scions. Tree Genetics \& Genomes 6(1): 57-72.

Juniper, B.E., Watkins, R. and Harris, S.A. (1996). The origin of the apple. In Eucarpia Symposium on Fruit Breeding and Genetics 484, Pp. 27-34.

Kelaniyangoda, D.B. and Heenkenda, H.M.S. (1993). Diagnosis and control of some important fungal diseases in improving apple and pear production in upcountry. Paper presented for the Diversified Agriculture Research Project, In-Service Training Institute, Peradeniya, Sri Lanka.

Koutinas, N., Pepelyankov, G. and Lichev, V. (2010).
Flower induction and flower bud development in apple and sweet cherry. Biotechnology and Biotechnological Equipment 24(1): 1549-1558.

Kron, P., Husband, B.C., Kevan, P.G. and Belaoussoff, S. (2001). Factors affecting pollen dispersal in highdensity apple orchards. HortScience 36(6): 1039-1046.

Kuffel Creek, Apple Tree Nursery (2018). Apple trees for hot climates and the tropics "we ship all over the world" Available from: http://www.kuffelcreek.com/ applenursery.htm (16 August 2020).

Larsen, B., Ørgaard, M., Toldam-Andersen, T.B. and Pedersen, C. (2016). A high-throughput method for genotyping S-RNase alleles in apple. Molecular Breeding, 36(3): 24.

Legave, J.M., Blanke, M., Christen, D., Giovanni, D., Mathew, V. and Ogerm R. (2013). A comprehensive overview of the spatial and temporal variability of apple bud dormancy release and blooming phenology in Western Europe. International Journal of Biometeorology 57: 317-331.

Matsumoto, S. and Kitahara, K. (2000). Discovery of a new self-incompatibility allele in apple. HortScience 35(7): 1329-1332.

Nesme, T., Bellon, S., Lescourret, F. and Habib, R. (2006). Survey-based analysis of irrigation and $\mathrm{N}$ fertilisation practices in apple orchards. Agronomy for Sustainable Development 26(3): 215-225.

Orcheski, B. and Brown, S. (2012). A grower's guide to self and cross-incompatibility in apple. NY Fruit Quarterly 20(2): 25-28.

Perera, T. and Madhujith, T. (2012). The pattern of consumption of fruits and vegetables by undergraduate students: a case study. Tropical Agricultural Research 23(3): 261-271.

Porat, R., Lichter, A., Terry, L.A., Harker, R. and Buzby, J. (2018). Postharvest losses of fruit and vegetables during retail and in consumers' homes: Quantifications, causes, and means of prevention. Postharvest Biology and Technology 139:135-149.

Porebski, S., Bailey, L.G. and Baum, B.R. (1997). Modification of a CTAB DNA extraction protocol for plants containing high polysaccharide and polyphenol components. Plant Molecular Biology Reporter 15(1): 8-15.

Sri Lanka Standards Institute, (2020). SLS 1572: Table apple - Covers the requirements of fruits of commercial varieties of apples grown from Malus domestica of the Rosaceae family, to be supplied fresh to the consumer, after preparation and packaging. Available from: https://www.slsi.lk/index.php?option=com slstandards\&view $=$ search_standards\&Itemid $=353 \quad(2 \overline{0}$ August 2020).

Rupasinghe, H.V., Wang, L., Huber, G.M. and Pitts, N.L. (2008). Effect of baking on dietary fibre and phenolics of muffins incorporated with apple skin powder. Food Chemistry 107(3): 1217-1224.

Ruto. J. (2018). Fact sheet on apple farming. Available from: http://farmbizafrica.com/high-yield/2408-factsheet-on-apple-farming (16 August 2020).

Sakurai, K., Brown, S.K. and Weeden, N. (2000). Selfincompatibility alleles of apple cultivars and advanced 
selections. HortScience 35(1): 116-119.

Troggio, M.I.C.H.E.L.A., Gleave, A., Salvi, S., Chagné, D., Cestaro, A., Kumar, S., Crowhurst, R.N. and Gardiner, S.E. (2012). Apple, from genome to breeding. Tree Genetics and Genomes 8(3): 509-529.

US Apple Association (2019). The voice of the apple industry. Available from: USapple.org. (06 August 2020).

van der Sluis, A.A., Dekker, M., Skrede, G. and Jongen, W.M. (2002). Activity and concentration of polyphenolic antioxidants in apple juice. 1. Effect of existing production methods. Journal of Agricultural and Food Chemistry 50(25): 7211-7219.

Weerahewa, J., Rajapakse, C. and Pushpakumara, G. (2013). An analysis of consumer demand for fruits in Sri Lanka. 1981-2010. Appetite 60 :252-258.

World Fruit Map (2018). Global trade still fruitful. Available from: https://research.rabobank.com/far/en/ sectors/regional-food-agri/world_fruit_map_2018.html (16 August 2020). 